\title{
Five Years Follow-Up of Posttraumatic and Postviral Olfactory Disorders and Analysis of Quality of Life
}

\author{
Jae-Hoon Lee and Sang-Woo Yoo \\ Department of Otolaryngology-Head \& Neck Surgery, Institute of Wonkwang Medical Science, School of Medicine, \\ Wonkwang University, Iksan, Korea
}

\author{
두부 외상과 상기도 감염 후에 발생한 후각장애의 5년 후 추적 관찰 및 삶의 질 분석 \\ 이 재 훈·유 상 우 \\ 원광대학교 의과대학 이비인후과학교실
}

Received May 11, 2012

Revised July 2, 2012

Accepted July 9, 2012

Address for correspondence

Jae-Hoon Lee, MD

Department of Otolaryngology-

Head \& Neck Surgery,

Institute of Wonkwang

Medical Science,

School of Medicine,

Wonkwang University,

895 Muwang-ro,

Iksan 570-711, Korea

Tel +82-63-859-1441

Fax $+82-63-841-6556$

E-mail coolnose@wmc.wonkwang. ac.kr
Background and Objectives Posttraumatic olfactory disorder is an olfactory loss following head trauma and postviral olfactory disorder is an olfactory loss following an upper respiratory infection, with symptoms often being demonstrating less interest in eating and exhibiting emotional impairment. As there is a lack of research regarding the long-term recovery rate of olfactory disorders, this study aims to determine that of both olfactory disorders and describe the quality of life (QOL) in the patients.

Subjects and Method Olfactory recovery was investigated in the first and recent visits (minimal 5 years follow-up) of 18 posttraumatic olfactory disorder patients and 14 postviral olfactory disorder patients. A total of 32 patients completed 6 items of QOL questionnaire ranging from 0 to 10 .

Results Five $(27 \%)$ of the 18 posttraumatic olfactory disorder patients showed olfactory improvement. Nine $(64 \%)$ of 14 postviral olfactory disorder patients showed olfactory improvement. The mean overall rating of QOL was increased according to the severity of olfactory impairment $(p<0.001)$.

Conclusion The long-term follow-up may be important to assess the olfactory disorder patients. The quality of life such as eating habits, depressive mood, and safety issues may be altered in the olfactory disorder patients.

Korean J Otorhinolaryngol-Head Neck Surg 2012;55:482-6

Key Words Disease $\cdot$ Follow-up study $\cdot$ Quality of life $\cdot$ Smell.

\section{서 론}

인간의 후각기능은 음식의 냄새나 꽃의 향기를 통해 쾌감을 느끼게 해주며, 상한 음식 냄새, 연기 및 가스 냄새의 탐지를 통 해 오염되고 위험으로부터 우리를 보호한다. 후각장애의 원인 으로는 크게 비부비동 질환, 상기도 감염, 두부 외상, 특발성 원 인 등으로 나눌 수 있다. 상기도 감염에 의한 후각장애는 가장 흔한 후각장애의 하나로 상기도 감염이 해결된 후에도 지속적 으로 후각장애가 남아 있는 경우를 말한다. 바이러스에 의한 후 각 신경의 손상에 의해 발생하는 것으로 알려져 있으나 아직 정
확한 기전은 밝혀져 있지 않다. ${ }^{1)}$ 두부 외상으로 인한 후각장애 는 갑자기 발생하며, 두부 외상 환자들은 후각감퇴보다는 후각 소실을 더 많이 호소하고 예후가 나쁘다고 알려져 있다. ${ }^{2)}$

후각의 경우 시각과는 달리 현재까지 정립된 객관적 검사법 이 개발되어 있지 않아 정확한 평가의 어려움이 있을 뿐만 아 니라 현재까지 여러 가지 치료 방법들이 소개되어 있으나 효과 가 입증된 것이 없어 치료에 많은 어려움을 겪고 있다. 후각장 애의 원인에 따른 예후에 대한 연구 또한 부족한 실정이다. 최 근 사회, 경제의 발전과 더불어 생활 수준이 높아짐에 따라, 후 각장애를 삶의 질을 낮추는 질병으로 인식하고 병원을 찾는 환 
자들이 증가하고 있다. 국내의 연구에서 후각장애 환자에서의 장시간 경과 후 후각회복에 대한 보고가 거의 없는 실정이다. 본 연구의 목적은 상기도 감염과 두부 외상으로 인한 후각장애 환자를 대상으로 장시간 경과 후 후각회복에 대한 추이 및 후 각장애로 인한 삶의 질을 평가하고자 하였다.

\section{대상 및 방법}

\section{대 상}

2003년 1월부터 2006년 6월까지 본 병원에 후각감퇴 및 후 각소실을 주소로 처음 외래 방문한 환자를 대상으로 외래 방 문시 작성된 병력, 후각검사 결과 및 이학적 검사 기록지, 방사 선학적 검사소견 등을 조사하였다. 후각장애의 정도를 측정하 는 검사는 한국형 후각검사 Korean Version of Sniffin' Sticks Test(KVSS Test)를 이용하였고, olfactory Threshold, odor Discrimination, odor Identification score(TDI score)로 후각장 애의 정도를 측정하였다. TDI score는 정상후각은 30점 이상, 후각감퇴는 16 29점, 후각소실은 15점 이하로 하였다.

두부 외상 및 상기도 감염의 경우는 알레르기 및 비용과 같 은 비부비동 질환이 없으면서 병력 청취상 후각기능장애 발생 전 3개월 이내 두부 외상 및 상기도 감염이 있었던 경우를 대 상으로 삼았다. 두부 외상인 경우 진료받은 기록지 혹은 진료소 견서를 통해 확인하였으며, 상기도 감염은 Sugiura 등에 의한 기준에 합당한 경우로 하였다. 소아의 경우는 주관적인 후각장 애의 표현이 부정확하고 검사자와의 협조가 어려워 그 결과를 신뢰하기 어렵다는 점과, 노인에서의 자연적인 후각감퇴 등을 고려해 처음 내원 당시 환자의 연령을 15 세 이상 60 세 미만으 로 제한하였다.

\section{장시간 경과 후 후각회복에 대한 추이}

2003년 1월부터 2006년 6월까지 본 병원에 내원하여 두부 외 상 및 상기도 감염으로 인한 후각장애로 진단된 환자 중 2011 년 9월부터 11월 사이 본 병원에 내원이 가능했던 환자를 대상 으로 하였다. 이 기간에 내원한 환자들을 대상으로 이학적 검 사, KVSS test를 이용한 후각검사를 실시하였고 삶의 질을 평 가할 수 있는 간단한 설문지를 작성하도록 하였다(Table 1). 연 구 대상은 후각장애로 본 병원을 처음 내원한 지 최소 5년 이 상 경과한 환자였으며 두부 외상으로 인한 후각장애는 18 명, 상 기도 감염으로 인한 경우는 14 명이었다.

\section{통 계}

후각소실군과 후각감퇴군 간의 삶의 질 점수 및 성별에 따른 후각소실군과 후각감퇴군에서의 삶의 질 점수를 평균표준
Table 1. Items of quality of life (QOL) questionnaire

\begin{tabular}{ll}
\hline Items & \\
\hline QOL 1 & 후각장애로 인해 식욕저하가 있나요? \\
QOL 2 & 식욕저하로 체중이 감소하였나요? \\
QOL 3 & 후각장애로 인해 요리하는 데 어려움이 있나요? \\
QOL 4 & 맛을 구별하기 힘드나요? \\
QOL 5 & 후각장애로 인해 위험에 처한 적이 있나요?(예, 음식 태우기, \\
& 상한 음식먹기, 가스누출) \\
QOL 6 & 후각장애로 인해 우울한 기분이 드나요?
\end{tabular}

Score by visual analogue scale ranging from 0 to 10 (0: meaning no discomfort at all, 10: meaning unbearable discomfort)

편차로 나타내고, 평균비교는 Student's t검정을 사용하였다. 유 의성은 $p$ 값이 0.05 미만인 경우, 통계적으로 유의하다고 판정 하였다.

\section{결 과}

\section{처음 내원시 연구 대상군의 특성}

전체 환자는 32명이었으며, 두부 외상으로 인한 후각장애였 던 경우는 18 명이었다. 남자는 14 명, 여자는 4명이었다. 처음 내 원시 평균나이는 $40.9 \pm 13.7$ 세였고, 후각검사에서 후각감퇴는 2 명, 후각소실은 16 명이었다. 상기도 감염으로 인한 후각장애

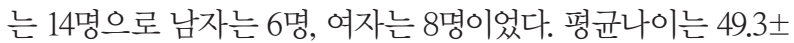
10 세였고, 후각감퇴는 6 명, 후각소실은 8명이었다.

\section{처음 내원시와 5 년 이상 장시간 시간경과 후에 따른 후각 변화 추이}

두부 외상으로 인한 후각장애였던 총 18명 중 처음 내원시 후각소실을 보였던 16 명은 5 년 이상의 장기간 시간 경과 후에 12명은 후각소실, 4명은 후각감퇴를 보였다(Fig. 1). 처음 내원 시 후각감퇴를 보였던 2 명 중 1 명은 후각소실, 1 명은 정상후각 을 보였다. 총 18명 중 5명(27\%)에서 후각호전을 보였다(Fig. 1).

상기도 감염으로 인한 총 14 명 중 처음 내원시 후각소실을 보였던 8명은 5년 이상의 장시간 경과 후에 2명은 후각소실, 3 명은 후각감퇴, 3명은 정상후각을 보였다(Fig. 2). 처음 내원시 후각감퇴를 보였던 6 명 중 후각소실은 없었고, 3 명은 후각감퇴, 3 명은 정상후각을 보였다. 총 14 명 중 9명(64\%)에서 후각호전 을 보였다(Fig. 2).

\section{설문지를 통한 삶의 질 분석}

2011년 9월부터 11월 사이 본 병원에 내원이 가능했던 환자 를 대상으로 외래에서 6 가지 항목으로 구성된 간단한 설문지 를 작성하도록 부탁하였다(Table 1). 각 문항당 10 점으로 가장 불편한 경우 10 점, 전혀 불편하지 않은 경우를 0 점으로 하여 총 점을 60점으로 하였다. 


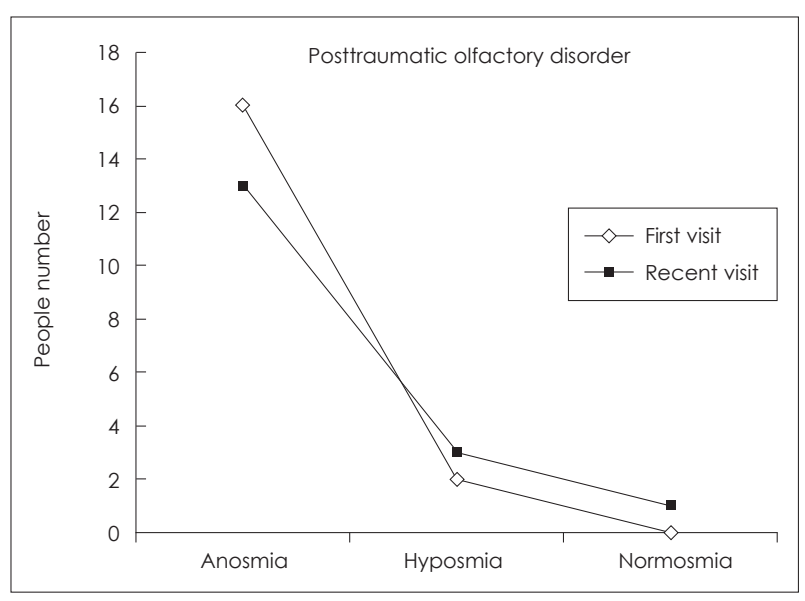

Fig. 1. Olfactory comparison in the first and recent visits (minimal 5 years long-term follow-up) of posttraumatic olfactory disorder patients. Five $(27 \%)$ of the 18 posttraumatic olfactory disorder patients showed olfactory improvement.

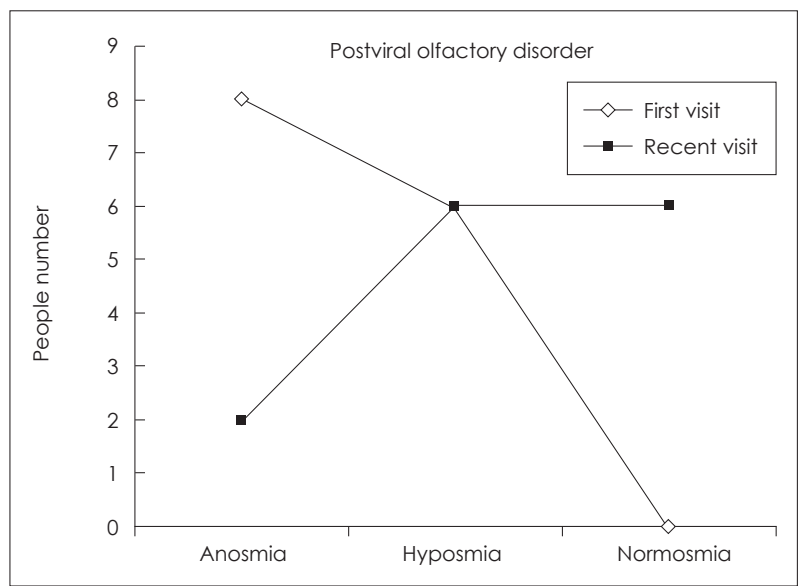

Fig. 2. Olfactory comparison in the first and recent visits (minimal 5 years long-term follow-up) of postviral olfactory disorder patients. Nine $(64 \%)$ of 14 postviral olfactory disorder patients showed olfactory improvement.

두부 외상 및 상기도 감염으로 인한 후각장애였던 총 32명 중 최근까지 후각소실을 보였던 15명에서 QOL 1 항목(후각장 애로 인해 식욕저하가 있나요?)에 대해 평균 5.1점, QOL 2 항 목(식욕저하로 체중이 감소하였나요?)은 4.9점, QOL 3 항목 (후각장애로 인해 요리하는 데 어려움이 있나요?)은 3.8점, $\mathrm{QOL}$ 4 항목(맛을 구별하기 힘드나요?)은 7.6점, QOL 5 항목(후각장 애로 인해 위험에 처한 적이 있나요? 예, 음식 태우기, 상한 음 식먹기, 가스누출)은 2.6점, QOL 6 항목(후각장애로 인해 우울 한 기분이 드나요?)은 6.9점이었다. QOL 4 항목인 맛을 구별 하기 어려운 경우와 QOL 6 항목인 후각장애로 인해 우울한 기분이 드는 질문에 높은 점수를 보였다. 상대적으로 QOL 5 항목인 후각장애로 인해 위험에 처한 적이 있는지에 대한 질 문에 낮은 점수를 보였다(Fig. 3).

두부 외상 및 상기도 감염으로 인한 후각장애였던 총 32명

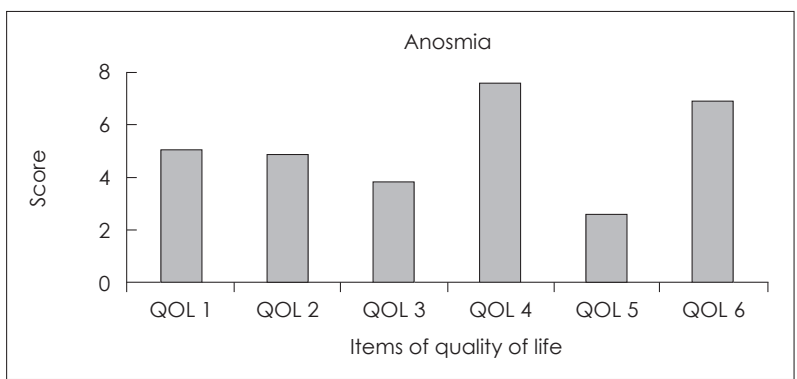

Fig. 3. Each mean score according to the 6 items of quality of life (QOL) questionnaire in the anosmic patients. The mean scores of QOL 4 and 6 show higher than those of the others.

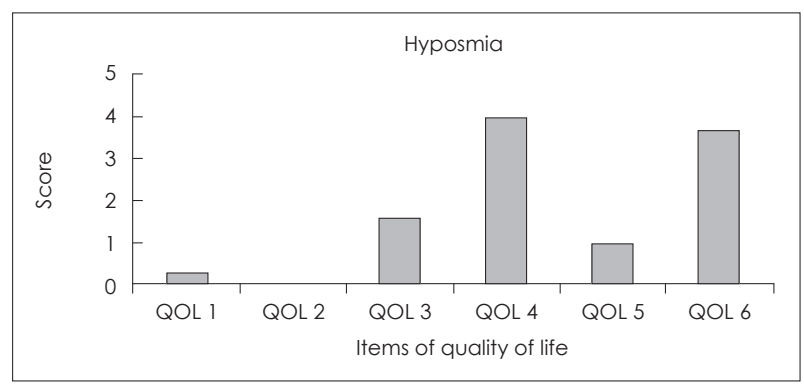

Fig. 4. Each mean score according to the 6 items of quality of life (QOL) questionnaire in the hyposmic patients. The mean scores of QOL 4 and 6 show higher than those of the others.

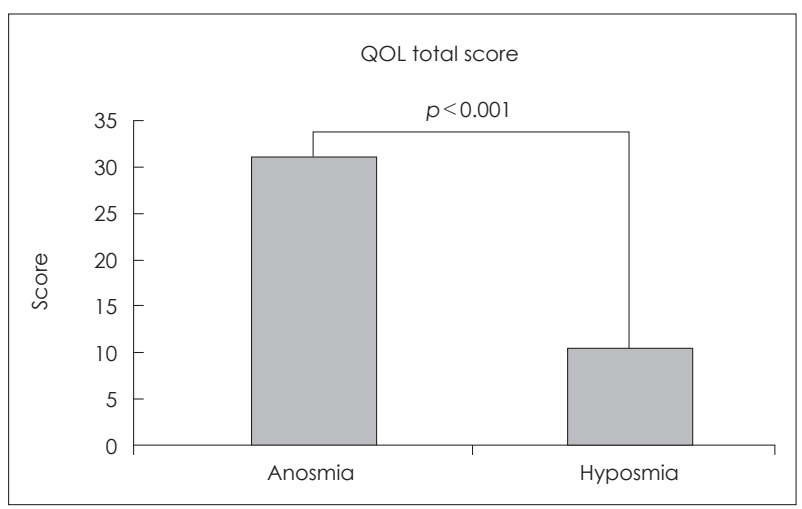

Fig. 5. Comparison of mean total score according to the 6 items of quality of life (QOL) questionnaire in the anosmic and hyposmic patients. The mean overall rating of QOL was increased according to the severity of olfactory impairment $(p<0.001)$.

중 최근까지 후각감퇴를 보였던 9명에서 QOL 1 항목에 대해 평 균 0.3점, $\mathrm{QOL} 2$ 항목은 0점, QOL 3 항목은 1.6점, QOL 4 항목 은 4점, QOL 5 항목은 1점, QOL 6 항목은 3.7점였다. QOL 4 항목인 맛을 구별하기 어려운 경우와 QOL 6 항목인 후각장애로 인해 우울한 기분이 드는 질문에 상대적으로 높은 점수를 보였 고, 기타 나머지 항목에서는 매우 낮은 점수를 보였다(Fig. 4).

QOL 1 6 항목의 점수에 대해 후각소실 환자와 후각감퇴 환자의 비교에서 후각소실 환자는 총점 60점에 평균 $31.1 \pm$ 13.5점, 후각감퇴 환자는 평균 10.6 \pm 7.3점으로 유의한 차이 를 보였다 $(p<0.001)$ (Fig. 5). 


\section{고 찰}

후각장애의 여러 원인 중 두부 외상 환자군의 경우, 평균 연 령이 다른 원인군들과 비교했을 때 낮으며 남성의 숫자가 여성 보다 많다고 보고되었다. ${ }^{4)}$ 이는 젊고 활동적인 연령의 남성 환 자군에서 외상으로 인한 후각장애의 가능성이 높기 때문일 것 으로 생각된다. 한편 두부 외상 환자들은 후각 기능검사상 후 각감퇴보다는 후각소실을 더 많이 호소하고 다른 원인군보다 예후가 나쁘다고 알려져 있다. 본 연구에서 평균나이는 40.9세 로 남자가 14명, 여자가 4명으로 남자가 여성보다 많았다. 교통 사고 뿐만 아니라 산업재해로 인한 원인이 일부 포함되어 평균 나이가 증가한 이유로 생각된다.

상기도 감염에 의한 후각장애 환자들은 연령이 높고 여성 이 대부분을 차지한다고 알려져 있는데," ${ }^{5}$ 본 연구에서 평균나 이는 49.3세, 여자가 8명, 남자가 6명이었으며, 두부외상 환자군 보다 평균연령이 높았으며 여성에서보다 많이 발생하였으나 남 성과의 유의한 차이는 보이지 않았다.

Doty 등 ${ }^{\circ}$ 은 펜실베니아대학의 후각 및 미각센터에서 두부 손상 후의 후각장애가 있는 286 명의 환자 중 $66.8 \%$ 가 후각소 실이었고 $20.5 \%$ 가 후각감퇴 환자였으며 거의 모든 환자에서 후각이 크게 향상되지 못하였음을 보고하였다. Seiden과 Dun$\operatorname{can}^{7}$ 은 두부 외상에서 후각소실과 후각감퇴가 각각 $73 \%, 27 \%$ 라고 보고하였다. 본 연구에서는 후각소실이 16 명으로 $89 \%$, 감 퇴가 2 명으로 $11 \%$ 로 처음 내원 당시 후각소실 환자가 많았다.

Seiden과 Duncan”은 상기도 감염에 의한 후각감퇴가 $57 \%$, 후각소실이 43\% 였다고 보고하였고, Yamagishi 등은 상기도 감염에 의한 환자 70 명 중 후각감퇴가 $47 \%$, 후각소실이 $53 \%$ 였다고 보고하였다. Quint 등')은 상기도 감염에 의한 환자 중 3 개월 이내에 병원을 방문한 환자의 $16 \%$ 는 후각감퇴를, $84 \%$ 는 후각소실이 있었으나, 3 개월에서 6 개월 사이에 방문하는 환자 의 $38 \%$ 가 후각감퇴 되었다고 보고하였다. 이런 변화는 시간 경 과에 따른 후각 기능의 회복을 의미한다고 보고하였다. 본 연 구에서는 상기도 감염에 의한 경우 후각감퇴가 6 명으로 $43 \%$, 후각소실은 8 명으로 $57 \%$ 였으며, 그전의 보고들 ${ }^{7-9}$ 과 유사하 였다.

상기도 감염으로 인한 후각장애로 1년 이내에는 후각 기 능 향상이 거의 미미하지만 1년 이상 경과 관찰한 환자들에서 는 어느 정도 후각 기능의 향상이 나타난 것으로 보고되었다. ${ }^{10}$ 이 연구에 따르면 상기도 감염에 의한 후각장애를 가진 21 명 의 환자들을 평균 36.9 개월의 추적 관찰을 하였는데, 그 중 $90 \%$ 에 달하는 19 명의 환자들이 펜실베니아대학의 후각검사(UP$\mathrm{SIT}$ )에서 추적관찰 기간 동안 점수가 향상되었으며, 그 중 13 명(62\%)은 후각을 느끼는 데 있어서 주관적으로도 더 나아진
것을 느낀 것으로 나타났다. 이 통계적 결과는 추적관찰 기간 과 후각 향상의 정도에 상당한 관련성이 있음을 시사하는 것 이다. 이러한 결과는 후각장애 후 1 2년이 후각회복에 영구적 인 기간이 아니며, 상피 세포 혹은 상피 세포와 후구 사이에 재 생 과정이 더 오랜 기간 지속된다는 것을 의미할 수 있다. 본 연 구에서 상기도 감염으로 인한 후각장애였던 총 14 명 중 5 년 이 상의 장시간 경과 후 9명(64\%)에서 후각호전을 보였다. 본 연구 에서 두부 외상으로 인한 후각장애였던 총 18 명 중 5년 이상 장시간 경과 후 5명 $(27 \%)$ 에서 후각호전을 보였다.

기분 상태나 전반적인 삶의 질을 알아보기 위한 평가법으로 Beck's Depression Inventory, the Mood Inventory, the Short Form-36 Health Survey 그리고 the General Well-Being Schedule 등이 소개되었다. ${ }^{11)}$ 후각 기능이 심하게 손상된 경우 후각 기능이 정상이거나 중등도 손상을 보이는 대상자에 비해 심 한 우울증과 함께, 인지 기능의 저하, 그리고 삶의 질 감소를 보 였다. ${ }^{12)}$ Tennen 드이) 은 후각 기능을 상실한 환자의 약 $17 \%$ 에서 중등도의 우울증이 나타나는 것으로 보고하였다. Temmel 등 ${ }^{4)}$ 은 278 명 조사 대상자의 거의 대부분이 일상 생활에서 후각장 애로 인한 어려움을 겪고 있다고 보고하였다. 그 중에서도 특 히 $73 \%$ 는 요리에서, $68 \%$ 는 기분의 변화, $56 \%$ 는 식욕의 감소, $50 \%$ 는 상한 음식을 먹게 되는 것, 30\%는 음식을 태우는 점 등 에서 불편을 호소했으나 직장에서의 문제는 $8 \%$ 밖에 되지 않 는 것으로 보고하였다. Mattes ${ }^{15}$ 의 연구 결과에 의하면 후각소 실 환자들은 음식의 섭취와 관련하여 체중의 증감을 경험하는 경우는 그리 많지 않았다고 보고하였으며, 후각 기능에 이상 후각증(dysosmia)과 같은 질적으로 이상이 생긴 경우에 있어 서 그 중 좀더 빈번하게 나타나는 것은 체중의 감소로 보인다 고 보고하였다.

본 연구에서 시행한 간단한 설문지를 통해 평가해 본 결과 후각소실을 보였던 환자군에서 후각감퇴를 보였던 환자군보 다 예상했던 대로 유의하게 높은 점수를 보였다. 후각소실군에 서 후각감퇴군보다 전반적으로 높은 점수를 보였고 $\mathrm{QOL} 4$ 항목인 맛을 구별하기 어려운 경우와 QOL 6 항목인 후각장애 로 인해 우울한 기분이 드는 질문에 높은 점수를 보였다. 상대 적으로 $\mathrm{QOL} 5$ 항목인 후각장애로 인해 위험에 처한 적이 있 는지에 대한 질문에 낮은 점수를 보였다. QOL 3 항목인 요리하 는 데 어려움이 있는지 하는 질문에는 낮은 점수를 보였는데 음 식을 만드는 일이 현실적으로 대부분 여성들이 하는 경우가 많 으므로 남성과 여성 환자를 전부 대상으로 하였으므로 상대적으 로 낮았을 것으로 생각되었다. 후각감퇴를 보였던 환자군에서 $\mathrm{QOL} 4$ 항목인 맛을 구별하기 어려운 경우와 QOL 6 항목인 후 각장애로 인해 우울한 기분이 드는 질문에 상대적으로 높은 점 수를 보였고, 기타 나머지 항목에서는 매우 낮은 점수를 보였다. 
현재까지 두부 외상 및 상기도 감염으로 인한 후각장애에 대한 효과적인 치료방법은 없기 때문에 환자에 대한 철저한 평 가 후에 생활 속에 발생할 수 있는 화재나 가스 누출시 인지하 는 능력이 떨어지므로 안전 문제에 대한 상담이 중요하다. ${ }^{4)}$ 후 각은 기분 좋은 향기와 맛있는 음식을 감지하여 일상생활을 즐 겁고 윤택하게 하여 삶의 질을 향상시키는 데 중요하다. 후각 장애 환자들은 음식 냄새를 맡을 수 없고 일부는 미각 장애를 동반할 수 있기 때문에 음식을 만들 때 곤란을 느끼며, 상한 음 식을 감별하기 힘들다. 따라서 가족들이나 주변의 도움이 반드 시 필요하다. 본 연구의 결과들에 의해서 우울한 기분에 대한 질문에 높은 점수를 보였는데, 후각장애 환자에서는 심한 경우 우울증이나 대인 관계 기피 증상이 발생할 수 있으므로 필요 시 정신과 의사와 상담할 수 있도록 해야 한다.

본 연구의 한계로는 첫 번째로 연구 대상 환자군의 수가 충 분히 많지 않다는 점이다. 차후에 더 많은 대상의 연구가 필요 할 것으로 생각된다. 두 번째로 주기적인 추적관찰이 되지 않 아 시간에 따른 후각회복에 대한 추이를 아는데 제한점이 있 다는 점이다. 후각장애를 주소로 본 병원에 내원 시점에서 일 정 기간 약물 치료 후 5년 이상 경과한 후 후각변화에 대한 결 과이고 그 사이 주기적인 추적관찰이 되지 않았다. 세 번째로 후 각에 대한 삶의 질을 알아보는 데 항목이 적고 편향적일 수 있 다는 점이다. 외래 진료에서 보편적으로 많은 문항의 설문지 에 부담을 느끼는 환자분들이 많아 간단한 문항으로 구성하 였다. 그러나 QOL 3번과 5번 같은 경우 한국의 음식문화에서 는 아직도 여성인 경우에 음식을 장만하는 경우가 많아 성별 에 따른 편향성을 야기할 수 있는 항목이라 생각된다. 그리고 QOL 2번의 경우 후각장애로 인한 체중 감소와 관련이 많다는 보고들이 많으나 일부 연구에서는 후각장애로 인해 오히려 체 중 증가를 야기할 수 있다는 연구 ${ }^{11)}$ 도 있어 체중감소라는 부분 에 초점이 맞춰진 듯 하다. QOL 6번의 경우 우울한 기분에 대 한 항목인데 실제 우울증과는 차이가 있을 수 있으므로 보다 구체적인 항목들이 요구될 수 있다.

\section{Acknowledgments}

This research is supported by Wonkwang Medical Institute Research Grant 2010.

\section{REFERENCES}

1) Bae WY. Postviral olfactory disorder. Korean J Otorhinolaryngol-Head Neck Surg 2010;53(11):669-74.

2) Dhong HJ, Shin DB, Rho HI, Chung SK, Chu KC. Clinical analysis of olfactory disorders. Korean J Otorhinolaryngol-Head Neck Surg 2001; 44(9):946-50.

3) Sugiura M, Aiba T, Mori J, Nakai Y. An epidemiological study of postviral olfactory disorder. Acta Otolaryngol Suppl 1998;538:191-6.

4) Hong SC, Ahn JY, Cho JH, Lim DJ, Park GH. Clinical analysis of the etiology of Korean olfactory disorders. Korean J Otorhinolaryngol-Head Neck Surg 2008;51(8):717-21.

5) Hendriks AP. Olfactory dysfunction. Rhinology 1988;26(4):229-51. 6) Doty RL, Yousem DM, Pham LT, Kreshak AA, Geckle R, Lee WW. Arch Neurol 1997;54(9):1131-40.

7) Seiden AM, Duncan HJ. The diagnosis of a conductive olfactory loss. Laryngoscope 2001;111(1):9-14.

8) Yamagishi M, Fujiwara M, Nakamura H. Olfactory mucosal findings and clinical course in patients with olfactory disorders following upper respiratory viral infection. Rhinology 1994;32(3):113-8.

9) Quint C, Temmel AF, Schickinger B, Pabinger S, Ramberger P, Hummel T. Patterns of non-conductive olfactory disorders in eastern Austria: a study of 120 patients from the Department of Otorhinolaryngology at the University of Vienna. Wien Klin Wochenschr 2001;113(1-2):52-7.

10) Duncan HJ, Seiden AM. Long-term follow-up of olfactory loss secondary to head trauma and upper respiratory tract infection. Arch Otolaryngol Head Neck Surg 1995;121(10):1183-7.

11) Hummel T, Nordin S. Olfactory disorders and their consequences for quality of life. Acta Otolaryngol 2005;125(2):116-21.

12) Seo HS, Jeon KJ, Hummel T, Min BC. Influences of olfactory impairment on depression, cognitive performance, and quality of life in Korean elderly. Eur Arch Otorhinolaryngol 2009;266(11):1739-45.

13) Tennen H, Affleck G, Mendola R. Coping with smell and taste disorder. In: Getchell TV, Dory RL, Bartoshuk LM, Snow JB, editors. Smell and taste in health and disease. New York: Raven press;1991.p. 787-802.

14) Temmel AF, Quint C, Schickinger-Fischer B, Klimek L, Stoller E, Hummel T. Characteristics of olfactory disorders in relation to major causes of olfactory loss. Arch Otolaryngol Head Neck Surg 2002;128(6): $635-41$.

15) Mattes RD. Nutritional implications of taste and smell disorders. In: Doty RL, editor. Handbook of olfaction and gustation. New York: Marcel Dekker;1995. p.731-44. 